\title{
EARLY MODERN ENGLISH SCIENTIFIC MANUSCRIPTS IN THE HUNTERIAN COLLECTION: A PHYSICAL DESCRIPTION OF GUL, MS HUNTER 135
}

\author{
JESÚS ROMERO-BARRANCO \\ Universitat de València
}

\section{INTRODUCTION}

The early Modern English period has a great importance not only in terms of the standardisation of the English language but also in terms of the transition from the scholastic thought to the pragmatic or empirical way of thinking. In other words, if at the beginning of the sixteenth century practitioners were convinced that knowledge was based on authoritative texts, by the middle of the century they acknowledged that empiricism was the new way of constructing knowledge. Contrary to scholasticism, empiricism relied on observation as a source of knowledge and induction as a mode of knowing. ${ }^{2}$

${ }^{1}$ The present research has been funded by the Spanish Ministry of Science and Innovation (grant numbers FFI2014-57963-P and FFI2017-88060-P) and by the Autonomous Government of Andalusia (grant number P11-HUM7597). These grants are hereby gratefully acknowledged. Dr. Javier Calle-Martín also deserves sincerest gratitude for his comments on previous drafts of this paper.

2 I. Taavitsainen and P. Pahta, "Vernacularisation of Medical Writing in English: A Corpus-Based Study of Scholasticism," Early Science and Medicine, 3.2, 1998, p. 162; M. Gotti, "The Experimental Essay in Early Modern English," European Journal of English Studies, 5.2, 2001, p. 221; I. Taavitsainen, "Historical Discourse Analysis: Scientific Language and Changing Thought-styles," in T. Fanego, B. Méndez-Naya and E. Seoane (eds.), Sounds, Words, Texts and Change. Selected Papers from 11 ICEHL, Santiago de Compostela, 7-11 September 2000, 
This evolution of science entailed a redistribution of medical writing in the period that, helped by book production, spread widely especially after $1550^{3}$. This not only provoked the expansion of already existent text types, but also the incorporation of new ones to the panorama of early Modern English medical writing. The diffusion of this new science was possible due to the circulation of manuscripts and, from Caxton's introduction of the printing press in 1476 , of early printed books. Even though the ability to write and the availability of materials increased after 1500, cheap printed books saved the trouble and expense of writing. However, there were certain text types that were more prone to be handwritten, such as the tailored compilations of remedies from various sources, the students' notebooks, and records of the different treatments that a particular physician applied to patients ${ }^{4}$. From a linguistic point of view, this transition in the way knowledge was transmitted is due to the fact that genres "constitute dynamic systems that undergo change and variation over the course of time as sociocultural needs change, and genres change accordingly: old genres are adapted to new functions, new genres are created, and genres that have lost their function cease to exist." 5

Glasgow University Library, MS Hunter 135 (henceforth H135) is a case in point in the production of these innovative learned surgeries, as it contains a version of Guy de Chauliac's surgery with interpolations of Henry de Mondeville and others along with a collection of medical recipes. ${ }^{6}$ In the former, the author lists a series of medicines to heal the injury after a surgical operation, whereas in the latter a list of remedies for different maladies is provided. These two text types are characterised by their pragmatic nature, lacking the usual references to classical authors. All this considered, the present article has been conceived with the following structure: Section 2 describes the volume under study; Section 3 provides the physical description of the manuscript, focusing on palaeographic and codicological aspects; and, finally, conclusions are gathered in Section 4.

John Benjamins Publishing Company, Amsterdam and Philadelphia, 2002, pp. 204-207; I. Taavitsainen, "The Pragmatics of Knowledge and Meaning: Corpus Linguistic Approaches to Changing Thought-styles in Early Modern Medical Discourse," in A. H. Jucker, D. Schreier and M. Hundt (eds.), Corpora: Pragmatics and Discourse, Rodopi, Amsterdam and New York, 2009, p. 38.

${ }^{3}$ I. Taavitsainen, P. M. Jones, P. Pahta, T. Hiltunen, V. Marttila, M. Ratia, C. Suhr and J. Tyrkkö, "Medical Texts in 1500-1700 and the Corpus of Early Modern English Medical Texts," in I. Taavitsainen and P. Pahta (eds.), Medical Writing in Early Modern English, Cambridge University Press, 2011, pp. 10-11.

${ }^{4}$ I. Taavitsainen, P. M. Jones, P. Pahta, T. Hiltunen, V. Marttila, M. Ratia, C. Suhr and J. Tyrkkö, op. cit., pp. 10-11.

${ }^{5}$ I. Taavitsainen, "Changing Conventions of Writing: The Dynamics of Genres, Text Types, and Text Traditions," European Journal of English Studies, 5.2, 2001, p. 141; I. Taavitsainen, "The Pragmatics of Knowledge and Meaning: Corpus Linguistic Approaches to Changing Thought-styles in Early Modern Medical Discourse," p. 38.

${ }^{6}$ L. E. Voigts, "A Doctor and his Books: the Manuscripts of Roger Marchall (d. 1477)," in R. Beadle and A. J. Piper (eds.), New Science out of Old Books: Studies in Manuscripts and Early Printed Books in Honour of A. I. Doyle, Scolar Press, Aldershot, 1995, p. 261. 


\section{THE WITNESS}

H135 is housed in Glasgow University Library. Referenced MS Hunter 135 (Т.6.17), it is a sixteenth-century volume containing five treatises, the second and approximately half the third being the object of study in the present paper, that is, ff. $34 \mathrm{r}-121 \mathrm{v} .{ }^{7}$

- Medica Qvaedam (ff. hv-32v), Latin and English by unknown author. ${ }^{8}$

- De Chirvrgia Libri IV (ff. 34r-73v), English by unknown author.

- Medica Qvaedam (74r-159v), Latin and English by unknown author.

- Practica Chirvrgiae (ff. 159v-208v), Latin by John Arderne.

- Medica Qvaedam (ff. 208v-234v), Latin and some English by unknown author.

The remaining pages contain three tables of contents in ff. cr-hr, ${ }^{9} \mathrm{ff} .235 \mathrm{r}-242 \mathrm{v}$ and ff. $243 \mathrm{r}-244 \mathrm{v}$, respectively. While the two first tables of contents correspond to the texts in H135, the third does not, as it refers to a text entitled 'The Secrets of Alexis,' a very popular collection of medical and technical receipts due to its numerous editions in Italian and other European languages such as French, among others. ${ }^{10}$

Apart from the third table of contents, the existence of the other two in H135 shows how different readers would create different custom tables of contents according to their interests. It also reveals the existence of other former owners of the manuscript, with various preferences towards the different topics in the manuscript.

7 These two texts constitute the English component of H135: a surgical treatise (19,348 words) and a collection of medical recipes (19,482 words).

${ }^{8}$ This part of the manuscript is mainly composed of an alchemical treatise (ff. $3 \mathrm{v}-23 \mathrm{v}$ ) in Latin and English as well as a geographical treatise (ff. 24r-32v) in English.

9 In the Glasgow University Library catalogue, the first folios are enumerated following the Roman alphabet (a-h).

${ }^{10}$ J. Ferguson, "The Secrets of Alexis. A Sixteenth Century Collection of Medical and Technical Receipts," Proceedings of the Royal Society of Medicine, 24.2, 1930, p. 225. 


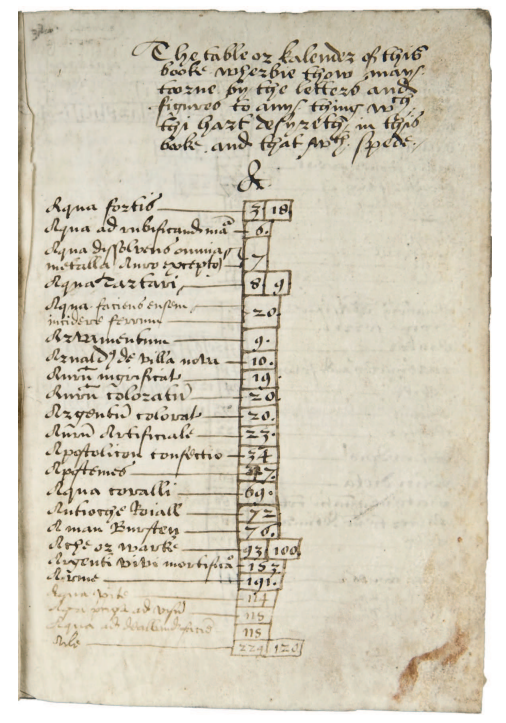

Fig. 1. Table of contents at the beginning

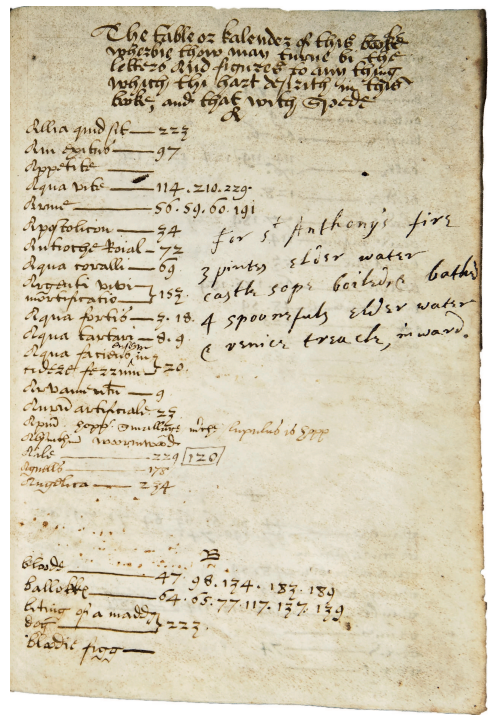

Fig. 2. Table of contents at the end

As observed in Figures 1 and 2, both tables of contents have the same introductory words and are arranged alphabetically, taking into account just the first letter of the word. Moreover, some parts of the texts are listed more than once in the same table of contents, albeit with different names (i.e. 'hering' and 'deafness').

Regarding the origin of the texts under study, the English medical recipes are, as far as I have been able to investigate, an original text inasmuch as they are recipes that were plausibly collected from different sources, from those coming directly from the Old English tradition to orally-transmitted ones. De Chirvrgia Libri, in turn, has been identified by Voigts, who states that there are four other versions of it in New York, Academy of Medicine, MS 13; Bodleian MS Ashmole 1468; and BL MS Sloane 2463 and 3486. This surgery is largely based on the Chirurgia Magna of Guy de Chauliac, with interpolations of Henry de Mondeville and others. ${ }^{11}$

\section{Physical description}

The present section addresses the physical description of H135. These data are the result of the examination of the digitised images provided by the Glasgow University Library, together with a meticulous in situ examination of the original witness. Young and Aitken's A Catalogue of the Manuscripts in the Library of the Hunterian Museum in the University of Glasgow (1908) has also been helpful.

\footnotetext{
${ }^{11}$ L. E. Voigts, op. cit., p. 261.
} 


\subsection{Codicology}

\subsubsection{Material and dimension}

H135 is a bound volume written in vellum, approximately 31 lines to a page in a single textblock. ${ }^{12}$ Parchment was the chief surface upon which scribes performed their task. This material was generally made from the skin of sheep or goats (sheep-skin prevailed in England), although the skin of lambs, kids or calves was employed for important manuscripts, hence the name vellum, from the Latin vellis, meaning calf. ${ }^{13}$

H135 comprises 245 vellum leaves that are $19.6 / 20.3 \times 14.8 / 15.3 \mathrm{~cm}$, the text occupying an area of $15.2 \times 10.1 \mathrm{~cm}$. The volume's dimensions are $21 \times 16.1 \times 6.3 \mathrm{~cm}$ (length, width, depth). The vellum is in overall good condition, the versos being whiter than the rectos, showing a yellowish colour. According to Hector, in almost all parchment there is a conspicuous difference in colour and texture between the flesh side and the hair side, the former being "whiter and somewhat smoother while the latter may be dark enough to be called "brown"". ${ }^{14}$ Some folios have become deteriorated due to the passing of time:

- ff. $6,44,169$ and 176 present a hole in the bottom margin.

- $\mathrm{f} .86$ is wrinkled due to dampness.

- f. 16 is spotted with stain.

- f. $32 \mathrm{v}$ is extremely stained, a fact that may explain the reasons why f. 33 is missing.

- ff. 40, 41, 46, 105 and 121 have sustained damage and loss at the outer margin (Figs. 3 and 4 below).

- ff. $\mathrm{b}$ and 245 are more deteriorated than the rest, pointing to the fact that these two folios were originally the cover and the back, respectively.

12 J. Young and P. Henderson-Aitken, A Catalogue of the Manuscripts in the Library of the Hunterian Museum in the University of Glasgow, James Maclehose and Sons, Glasgow, 1908, p. 122.

${ }^{13}$ A. G. Petti, English Literary Hands from Chaucer to Dryden, Edward Arnold Publishers Ltd., London, 1977, p. 4; C. de Hamel, Medieval Craftsmen: Scribes and Illuminators, British Museum Press, London, 1992, p. 8.

${ }^{14}$ L. C. Hector, The Handwriting of English Documents, Edward Arnold, London, 1958, p. 16. 


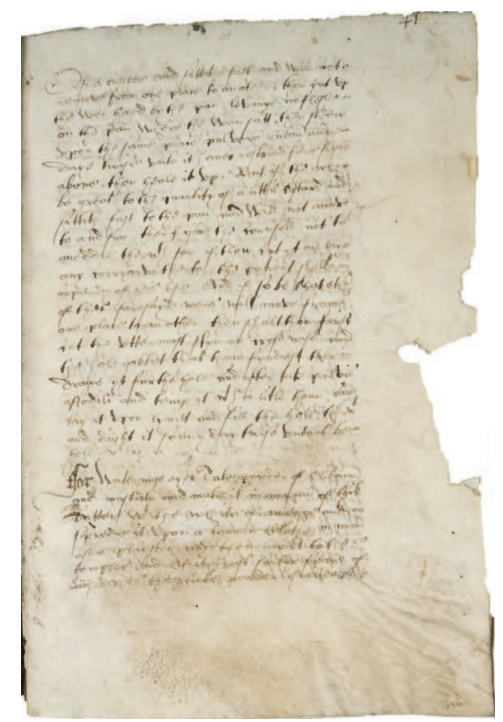

Fig. 3. Damage at the outer margin in $\mathrm{f} .41^{15}$

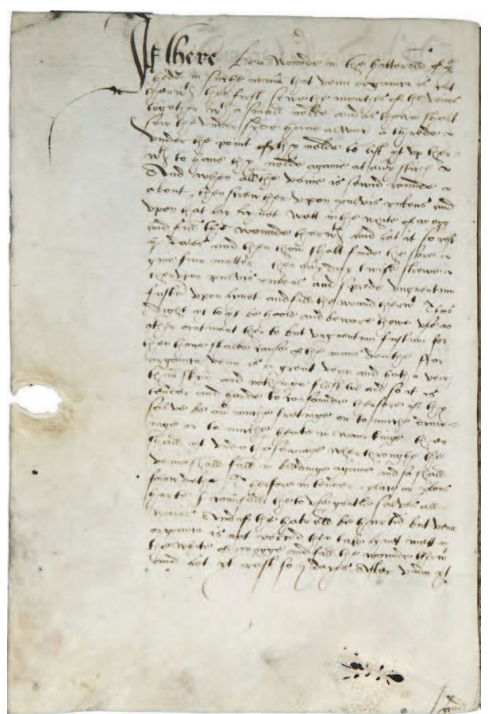

Fig. 4. A hole at the outer margin in f. 46

\subsubsection{Ink and decoration}

The inks employed in the production of manuscripts were thicker and more glutinous than modern commercial ink, and there were different recipes for their manufacture. It was basically black and could be made by mixing carbon with gum and water or from gall and iron sulphate. These recipes are found in numerous medieval and renaissance manuscripts, and H135 is not an exception to this as it contains a recipe 'To make blak ynk' in f. 174r, even though the nature of the remedies in that section of the volume is purely medical.

\section{To make blak ynk}

Take a pound and a half of rayn watter with 3 owncs of the weightiest galls you can get bruse theim into peeces but not into powder and powre theim into pe said water. and let it stand. 2. days in the sune then put to it 2 ouncs of romain vitriol being within like to the colour of be elyment and beat it into small powder and mix all well together with a stik of a fygg tree or walnut tre /or a peece of licores $\backslash$ and leave it again 2 days moore in the Sune / Finallie put to it one ownce of gume Aralyke that is clere brittill (for the best wilbe easelye Bet into powder) bet into powder and an ownce of the pills of pomgarnetts and then boile yt a lytill with a slow fier that doone streane it and kepe it in a vessel of lead or glasse and it wilbe vere perfite and blak and upon the lees that shall

${ }^{15}$ Notice the different shades in the vellum of these two folios, as f. 41r is slightly yellowish while f. $46 \mathrm{v}$ presents a whiter colour. 
remayne in pe bottom you may powr other water and boil it a litill and strean yt and you may still put moore water vpon pe same lees vntill you see that the water wilbe colored no moore with theim/Then mingle all the said waters wherunto you shall put other galls gums and vitriol as at the begynning and setting it in the Sune you shall haue a better ink then at the beginning (f. 174r).

H135 is written with brownish ink, whose shade varies throughout the manuscript, as shown below. Petti states that, "although initially [iron gall ink] became quite dark through oxidation, it eventually faded, sometimes to a quite light brown "shade"". ${ }^{16}$ Therefore, the varied brownish tonality of the ink in H135 leads us to think that it was iron gall ink or with added carbon.

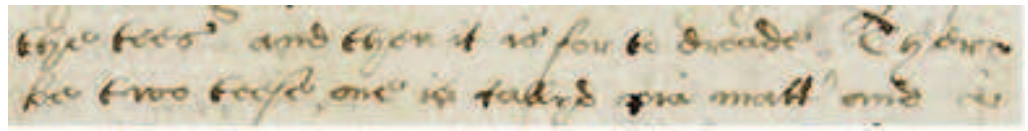

Fig. 5. f. 34r

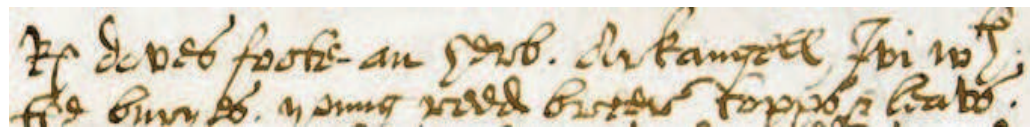

Fig. 6. f. $74 \mathrm{r}$

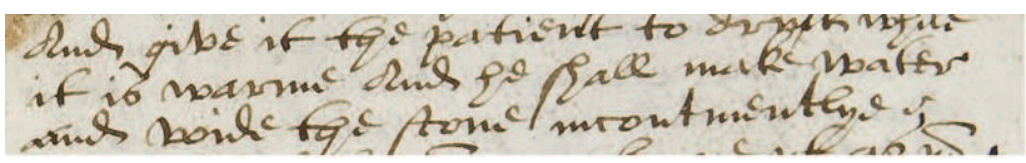

Fig. 7. f. $99 \mathrm{r}$

The decoration of manuscripts came after the text had been copied, where the scribe would leave room for rubrication, decoration and illustration. ${ }^{17}$ No completed medieval manuscript would lack any of these parts, as manuscripts were considered pieces of art. During the latter part of the Middle English and the beginning of the early Modern period, "innovation took place in the pictures that accompanied the text, while initials and other elements of decoration where more and more standardized due to production needs." 18

When it comes to decoration, the richest part of H135 is the treatise on surgery in ff. $34 \mathrm{r}-73 \mathrm{v}$. The beginning of the treatise and the beginning of relevant sections are decorated with a more elaborate script, bolder and darker than the body text. In addition, the end of each chapter is marked with an ornamented,

${ }^{16}$ A. G. Petti, op. cit., p. 8.

${ }_{17}$ R. Clemens and T. Graham, Introduction to Manuscript Studies, Cornell University Press, Ithaca and London, 2007, p. 20.

18 A. Derolez, The Palaeography of Gothic Manuscript Books. From the Twelfth to the Early Sixteenth Century, Cambridge University Press, Cambirdge, 2003, p. 40. 
bottom-centred Latin inscription. The lack of illumination or floral ornaments indicates that this volume may have been created by one single person, without the intervention of illuminators.

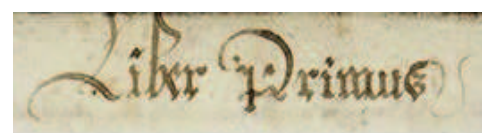

Fig. 8. Beginning of the surgical treatise (f. 34r), 'Liber Primus'

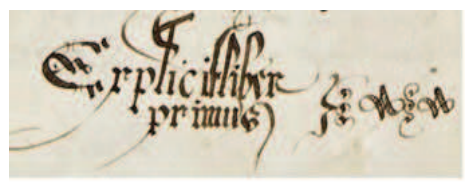

Fig. 10. End of the first chapter (f. 45v), 'Explicit Liber | Primus'

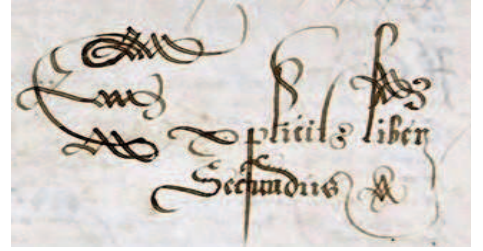

Fig. 9. End of the second chapter (f. 55r), 'Explicit Liber | Secundus'

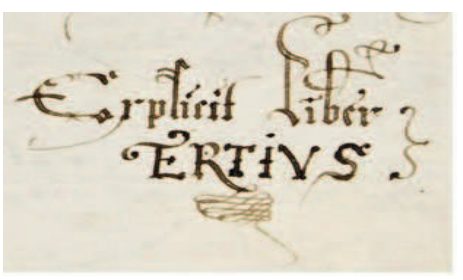

Fig. 11. End of the third chapter (f. 67r), 'Explicit Liber | Tertivs'

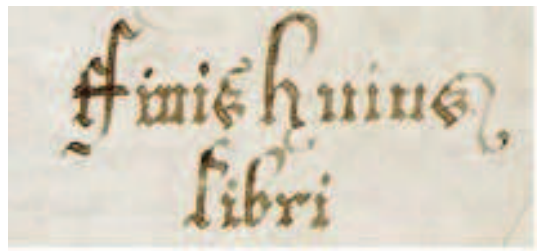

Fig. 12. End of the surgical treatise (f. 73v), 'Finis Huius Libri'

The only illustration in $\mathrm{H} 135$ is the head of a man where a dot is indicating the location of the pain. It appears in the outer margin of $f .90 \mathrm{v}$, containing a recipe against the migraine, and the ink used for its rendering allows us to determine that it was done by the same scribe who wrote the remedy. 


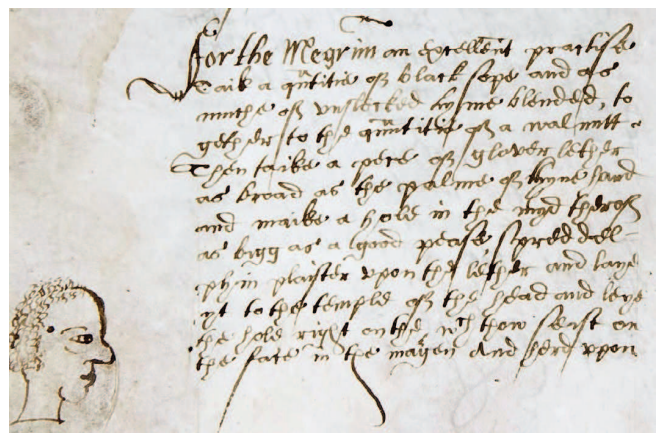

Fig. 13. Illustration of a head (f. 90v)

\subsubsection{Binding and quiring}

The binding was the last stage in the creation of a book, after the text had been copied, the folios illuminated and the illustrations included. According to De Hamel, it was the task of the stationer or bookseller, who would have to "collect up all the quires, reassemble them into order, and hold them together in some serviceable binding." 19

The first step was the sewing of the quires into the sewing supports in the spine of the book. ${ }^{20} 29$ quires were needed for the creation of H135, together with two flyleaves at the beginning of the volume and five at the end. The volume presents an irregular bifolia quiring, as some quires contain four bifolia (quires 1-19, 21, 23) and others contain five bifolia (quires 20, 22, 24-29). This was a regular practice during the Middle Ages, although "the relative thinness of the material often induced producers of books to use quires of more than four bifolia, indeed of six or up to twelve and even more bifolia." ${ }_{21}$

After sewing all the quires onto the sewing supports, the book was ready to incorporate the cover and the back, which were made of wood covered with pigskin, calfskin or goatskin. ${ }^{22}$ The binding in $\mathrm{H} 135$ is not original and it dates back to the eighteenth century. The cover is a millboard covered with spattered calfskin with the title 'MEDICAL $\mid$ \& CHIRURG. MS'. and the back is gilt-panelled. ${ }^{23}$

\footnotetext{
${ }^{19}$ C. De Hamel, op. cit., p. 65.

${ }^{20}$ R. Clemens and T. Graham, op. cit., p. 49.

${ }^{21}$ A. Derolez, op. cit., p. 32; J. Romero-Barranco, The Middle English Version of Constantinus Africanus' Venerabilis Anatomia in London, Wellcome Library, MS 290 (ff. 1r-41v), Cambridge Scholars Publishing, Newcastle Upon Tyne, 2015, p. 4.

${ }^{22}$ R. Clemens and T. Graham, op. cit., pp. 52-53.

${ }^{23}$ J. Young y P. Henderson-Aitken, op. cit., p. 122.
} 


\subsubsection{Ruling}

The ruling of the folios was usually performed by means of a pencil or plummet, and helped the scribe maintain the lines of the text straight. According to Petti, "before the writing commenced [...] a frame was provided for the writing area of each page and the lines ruled." ${ }^{24}$ In the late fifteenth century ruling became less fashionable and only the frame remained, an element that would be omitted from the sixteenth century. ${ }^{25}$

H135 only presents the frame for the text in each folio, made in plummet or pencil. ${ }^{26}$ Due to the fact that the plummet or pencil was used, the frame has been completely erased in most of the folios, and it is hardly recognizable in some others.

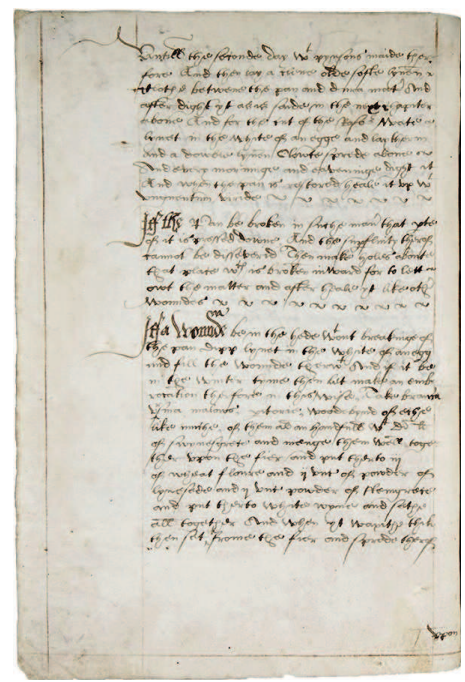

Fig. 14. Ruling in H135 (f. 35v)

\subsubsection{Foliation}

Foliation was conceived as an aid to the ordering of the folios, and also for referencing purposes. There were different ways of maintaining the quires in a manuscript in order: quire-marks or quire numerals consisted of a Roman numeral written in the lower margin of the first or last page of a quire; signatures indicated not only the order of the quires, but also of the bifolia of each quire; and catchwords (sometimes called stitchwords) were written at the end of each folio so that the scribe would know the first word in the next one. ${ }^{27}$

\footnotetext{
${ }^{24}$ A. G. Petti, op. cit., p. 6.

${ }^{25}$ Loc. cit., p. 6.

${ }^{26}$ J. Young y P. Henderson-Aitken, op. cit., p. 122.

${ }^{27}$ A. Derolez, op. cit., p. 35; R. Clemens and T. Graham, op. cit., p. 49.
} 
H135 features foliation in the top right corner of each folio recto, where the scribe includes the reference to each folio in Arabic numerals. Furthermore, catchwords, rendered in the same hand as the body text, are also witnessed in every folio with the only exception of the final folios of each chapter in the surgical treatise (ff. 34r-73v) and those folios in which the catchword has been lost most likely due to the re-binding process to which the volume was subjected.

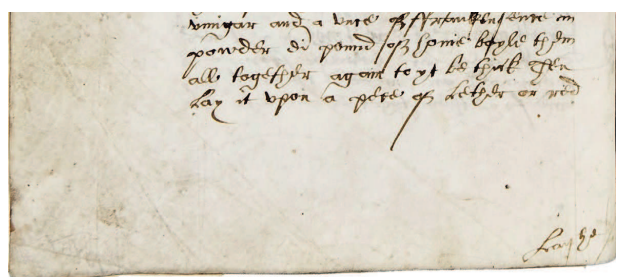

Fig. 15. Catchword in f. 93v, bottom margin. 'laishe'

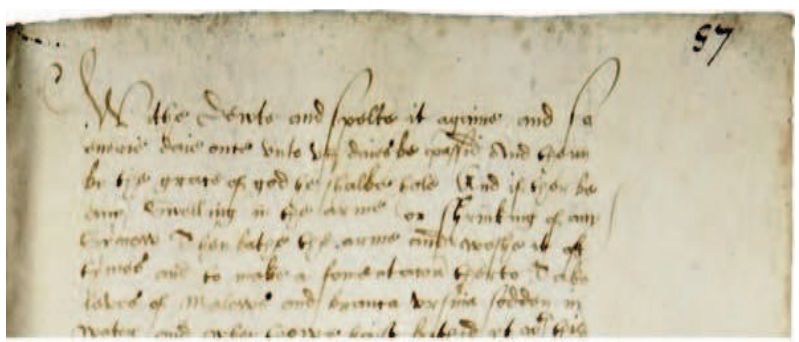

Fig. 16. Foliation in f. 57r, top margin

\subsection{Palaeography}

Denholm-Young points out that "the business of a palaeographer is not only to read, classify, date, and determine the provenance of a manuscript, but to recognize textual errors that spring from the scribe's misreading of what he is copying." ${ }^{28}$ Consequently, studies in Palaeography become particularly handy when it comes to the dating of historical manuscripts, as variation between two different scripts can be detected in any fifty-year period in the history of English handwriting. ${ }^{29}$

When it comes to handwriting in Tudor England, two different scripts can be distinguished: the Tudor Secretary and the Italic (also known as Humanistic or Italian). It must be noted that, while the Tudor Secretary script was the evolution of the former Secretary script that had been in use from the beginning

${ }_{28}^{2}$ N. Denholm-Young, Handwriting in England and Wales, University of Wales Press, Cardiff, 1954, p. 1.

${ }^{29}$ G. E. Dawson and L. Kennedy-Skipton, Elizabethan Handwriting 1500-1650. A Guide to the Reading of Documents and Manuscripts, Faber and Faber, London, 1968, p. 8. 
of the fifteenth century, the Italic was "a markedly new development in Tudor England." 30

The Secretary script was the usual hand from 1525 until about 1650, being used "for business both governmental and private, for many kinds of records, correspondence, for literary composition, etc." ${ }_{11}$ According to Tannenbaum, "this hand [...] followed the letterforms of the large bastard hand and [...] it was the finest of the free hands that developed from the bastard Gothic." ${ }_{32}$ For the sake of description and classification, Petti distinguished three different phases in the Secretary script: early Tudor Secretary, from the ascension of Henry VII to the throne until the later years of the reign of Henry VIII; the mid-Tudor Secretary, from the mid-1530s to about the beginning of Elizabeth's reign; and Elizabethan Secretary, from about 1560 onwards. ${ }^{33}$

The other characteristic script of the period is the Italic script, which became more and more popular in England after 1550. It developed in Italy towards the fifteenth century and it is considered to derive from the Caroline Minuscule. ${ }^{34}$ The success of this script was due to its simplicity and ease of writing, on the one hand, and its grace and beauty, on the other. It took over the Secretary's supremacy in England before 1650 and "ultimately brought about its demise." 35

These two hands coexisted and were sometimes mixed in various ways. Dawson and Kennedy-Skipton argue that "in the sixteenth century, and later, writers of the secretary hand often used the italic hand to set off certain elements, such as book titles, or to indicate emphasis." ${ }^{36}$

\subsubsection{Scripts}

The text in H135 is written using two different scripts. For the sake of description and comparison, these have been termed Hand A and Hand B in the present section. Apart from these two hands, the volume contains corrections and insertions by a later hand (henceforth Hand C), which is also described.

${ }^{30}$ J. F. Preston and L. Yeandle, English Handwriting 1400-1650. An Introductory Manual, Pegasus Press, Asheville and North Carolina, 1999, p. viii; see also H. Jenkinson, The Later Court Hands in England: from the Fifteenth to the Seventeenth Century, Frederick Ungar Publishing Co., New York, 1927, pp. 54-57; N. Denholm-Young, loc. cit., pp. 71-76; L. C. Hector, op. cit., p. 60; A. Fairbank and B. Wolpe, Renaissance Handwriting, Faber and Faber, London, 1960, pp. 28-34; G. E. Dawson and L. Kennedy-Skipton, loc. cit., pp. 7-10; A. G. Petti, op. cit., pp. 14-18; H. Marshall, Palaeography for Family and Local Historians, Phillimore, Hampshire, 2004, p. 23.

${ }^{31}$ G. E. Dawson and L. Kennedy-Skipton, loc. cit., p. 8.

32 S. A. Tannenbaum, The Handwriting of the Renaissance, Columbia University Press, New York, 1930, p. 13.

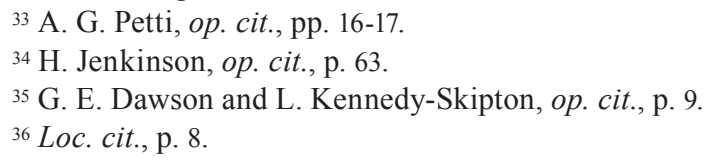


In addition, the handwriting of three owners of the volume are shown in Figures 17, 18 and 19, corresponding to William Hunter, Henry Swinburne and Leonardus Cooke, respectively.

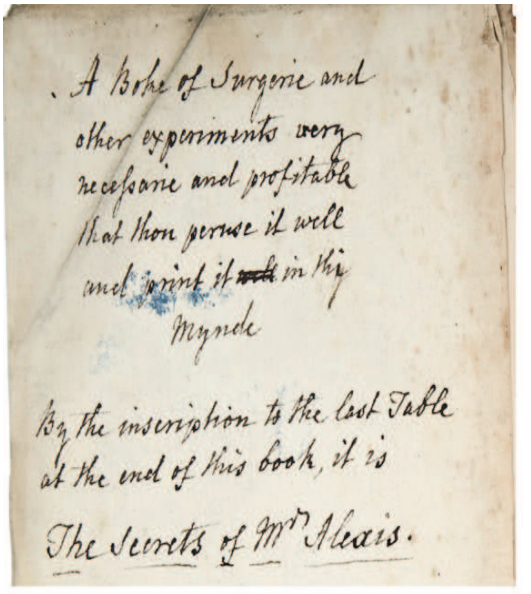

Fig. 17. William Hunter's own handwriting

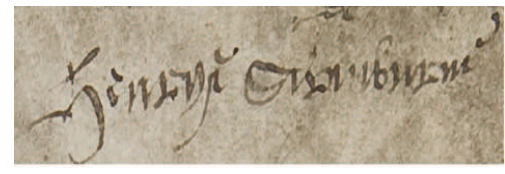

Fig. 18. Henry Swinburne's autograph

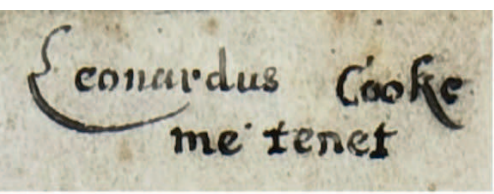

Fig. 19. Leonardus Cooke’s autograph

Leonardus Cooke's autograph is rendered in a late seventeenth-century hand, ${ }^{37}$ whereas Henry Swinburne's is written in an early seventeenth-century hand. William Hunter's handwriting, in turn, is a well-spaced cursive script that resembles our contemporary handwriting. Letter $<\mathrm{s}>$ is worth noting, represented by both sigma-like $<\mathrm{s}>$ and long $<\mathrm{s}>$.

\subsubsection{Hand $A$}

Hand $\mathrm{A}$ is the main hand in H135, occupying ff. $34 \mathrm{r}-73 \mathrm{v}, 74 \mathrm{v}-98 \mathrm{r}$ and $101 \mathrm{v}-$ $-113 \mathrm{v}$. Even though this hand is faithfully kept throughout these folios, some variation is observed in the thickness of the ductus and level of cursiveness. This variation could be said to derive from the speed with which the scribe was carrying out his task, as speed "not only modif[ies] scripts to save the labour of writing but will also save material by a reduction of size letters, or by lateral compression, or close spacing." 38

\footnotetext{
${ }^{37}$ A. Fairbank and B. Wolpe, op. cit., pl. 55.

${ }^{38}$ A. Fairbank, A Book of Scripts, Penguin Books, Maryland, 1968, p. 31.
} 


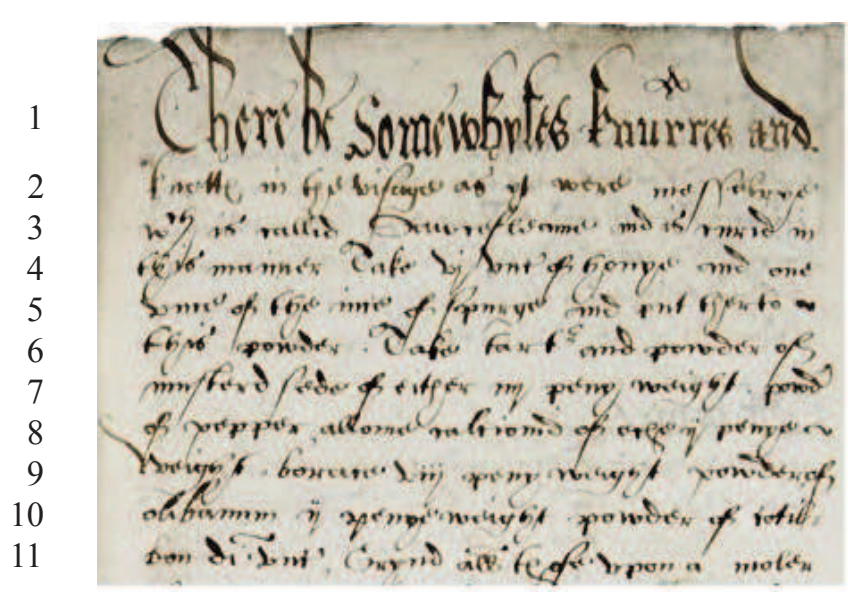

Fig. 20. Hand A (f. 45r)

The letterforms observed in Hand A, except for those in the title of sections (Figure 20 above, line 1), suggest that it is a hybrid script mainly composed of an early Tudor Secretary hand together with some characteristic features of the mid-Tudor Secretary and the Italic, which were in use in England towards the middle of the sixteenth century. ${ }^{39}$

Among the letterforms belonging to the early Tudor Secretary, the following stand out: the pointed single-lobed $<\mathrm{a}>$ ('callid', 'and', line 3); the uncial $<\mathrm{d}>$ ('musterd', line 7); the looped $<\mathrm{f}>$ inclined rightwards ('of', line 5); the tailed $\langle\mathrm{g}>$ with a wide $u$-shaped top and a long headstroke ('visage', line 2; 'weight', line 10); the letter $<\mathrm{k}>$ with a long supralinear stroke slightly curved rightwards, from which two small strokes stem out upward and downward, the upper one forming a lobe ('take', line 4); a vertical stroke with a small rightward lobe at the top for the $<\mathrm{l}>$ ('Sawcefleame', line 3); the letters $<\mathrm{m}>$ and $<\mathrm{n}>$ written with a single stroke, where the minims are slightly curved rightwards ('manner', line 4); the short-stemmed $<\mathrm{p}>$ in which the stroke of the lobe crosses the shaft ('penye', line 8); 40 the round $<u<$ written with a single stroke, resembling the shape of $<\mathrm{n}>$ ('spurge', line 5); the $<\mathrm{v}>$ written with two strokes, both of them being made from top to bottom ('visage', line 2);41 and the canonical secretary form of $<w>$ ('powder', line 9).

39 J. F. Preston and L. Yeandle, op. cit., pl. 11 and 13.

${ }^{40}$ Some words beginning in $\langle\mathrm{p}>$ systematically feature a long-stemmed $\langle\mathrm{p}>$ which is made in one single stroke. The contrast between these two renderings for $\langle\mathrm{p}\rangle$ can be checked against the word 'pepper' in line 8 (Figure 20).

${ }^{41}$ Hand $\mathrm{A}$ uses both $<\mathrm{u}>$ and $<\mathrm{v}>$ with a vocalic value, the former in medial and final position and the latter in initial position. 
The mid-Tudor-Secretary component in Hand A is represented by the single-lobed $<\mathrm{b}>$ with the shaft curved rightwards ('borace', line 9);42 the letter $<\mathrm{e}>$ where the eye is usually split from the body due to the thinness of the connecting stroke ('honye', line 4 ); the $<\mathrm{c}>$ with a vertical shaft from which a line stems out leftwards ('curid', line 3); and the twin-stemmed $<\mathrm{r}>$ resembling $v$ ('therto', line 5).

Finally, there are some letters that vary their shape due to arbitrariness or their position within the word. Thus, the letter $<\mathrm{h}>$ may arbitrarily feature an early Tudor Secretary shape ('this', line 4 ) or a shape clearly influenced by the Italic script ('those', line 11); the long $<_{\mathrm{S}}>$, in turn, is witnessed at initial and medial position ('spurge', line 5; 'musterd', line 7), while the Italic sigma-like $<_{\mathrm{S}}>$ is preferred in final position ('this', line 6); finally, the letter $<\mathrm{t}>$ is represented with the early Tudor vertical stem crossed at the top at initial position ('the', line 5), and with the mid-Tudor version rendered with one single stroke at medial and final position ('weight', line 7).

Apart from the body of the text, important sections are introduced by highlighted words or short sentences rendered with the Italic script, as in Figure 20. These letters are highlighted by means of a thicker ductus and a bigger size, which approximately doubles the size of letters in the body text. In the Italic script of H135, the following letterforms deserve particular attention: the uncial $<\mathrm{d}>$ ('and', line 1); the $<\mathrm{h}>$ written with a supralinear vertical loop followed by two semiovals, the first right-handed, the second left-handed and serving as the forelink ('There', line 1); the Italic sigma-like $<\mathrm{s}>$ ('knurres', line 1); and the letters $<\mathrm{e}>$ and $\langle\mathrm{w}>$ similar to their present-day realizations.

\subsubsection{Hand B}

Hand B, present in ff. $74 \mathrm{r}, 98 \mathrm{v}-101 \mathrm{r}$ and $113 \mathrm{v}-121 \mathrm{v},{ }^{43}$ is bigger and less cursive than hand $\mathrm{A}$, as well as thicker and more angular in the execution of the ductus. It is a hybrid script composed of an early Tudor Secretary combined with some characteristic letterforms of the mid-Tudor Secretary script. ${ }^{44}$ It must be noted that, even though both Hand A and B are hybrid scripts composed of early Tudor Secretary combined with mid-Tudor Secretary, Hand B is a purer early Tudor Secretary script, as it just contains two letterforms belonging to the mid-Tudor Secretary.

${ }^{42}$ This letter may also be represented in its double-lobed shape ('cotilbon,' line 10), although it seldom occurs.

${ }^{43}$ Apart from being the hand in these folios, this hand is also witnessed in the marginalia of ff. 40r, 43v, 44r, 52v, 54v, 56r-v, 57r, 58v, 69r, 72r, 74r, 81v, 82v, 97r, 99v, 100v, 109v, 110r, 114r, $114 \mathrm{v}, 115 \mathrm{r}-\mathrm{v}, 116 \mathrm{r}-\mathrm{v}, 117 \mathrm{r}-\mathrm{v}, 118 \mathrm{r}-\mathrm{v}, 119 \mathrm{r}-\mathrm{v}, 120 \mathrm{r}-\mathrm{v}, 121 \mathrm{r}$. These are mainly single words informing of the content of the adjacent text and short explanations about the topic involved.

${ }^{44}$ S. A. Tannenbaum, op. cit., pl. IX; G. E. Dawson and L. Kennedy-Skipton, op. cit., pl. 41; J. F. Preston and L. Yeandle, op. cit., pl. 14. 


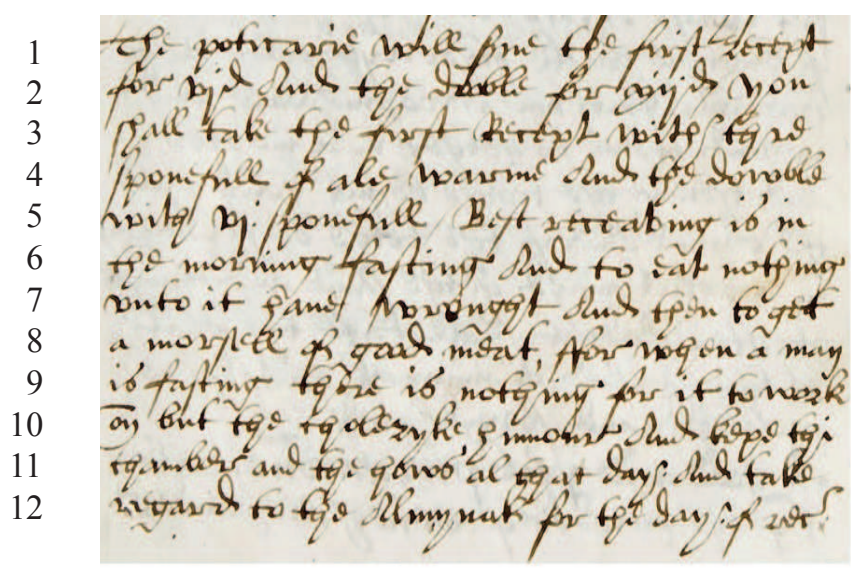

Fig. 21. Hand B (f. 99v)

The following letterforms, with an early Tudor Secretary shape, represent the divergences between Hands A and B: the double-lobed $<\mathrm{b}>$ ('chamber,' line 11); a short vertical stroke and a thin horizontal stroke at the top of it for the $<\mathrm{c}>$ ('receaving,' line 5); the reversed circular $<\mathrm{e}>$ ('the,' line 3); and a $z$-form for the $<\mathrm{r}>$ ('choleryke,' line 10). ${ }^{45}$ The letters representing the mid Tudor component of Hand B are the $<\mathrm{d}>$, which is losing its definition, and the $<\mathrm{p}>$, which has acquired a 2 to the left of the downward stroke ('poticarie,' line 1).

\subsubsection{Hand C}

Hand C (Figures 22 and 23) is the less frequent hand in H135 (ff. 45v, 76r, 85v, $102 \mathrm{v}$ ) and can only be witnessed in the marginalia. Even though it rarely appears in the two sections that concern the present paper, its presence spreads both in John Arderne's practice on surgery and the collection of medical recipes in Latin. ${ }^{46}$ It is the same hand that collated John Arderne's practice on surgery in T.5.14 (Glasgow University Library, MS Hunter 112), and adds marginalia, interlinear additions and corrections from U.4.9 (Glasgow University Library, MS Hunter 251), also containing a version of John Arderne's practice on surgery, referred to as 'Dr. Mead's MS.' 47 . It is a fairly legible seventeenth-century Round hand that came into use by the middle of the seventeenth century.48

${ }^{45}$ This shape is only observed in medial position, while the twin-stemmed $<\mathrm{r}>$ resembling $v$ is kept in initial and final position.

${ }^{46}$ The fact that these inscriptions refer to Dr Mead's manuscript allows us to conclude that H135, MS Hunter 112 and MS Hunter 251 somewhat shared the same owner, who made these inscriptions.

${ }^{47}$ J. Young y P. Henderson-Aitken, op. cit., p. 122.

${ }^{48}$ A. G. Petti, op. cit., p. 20. 


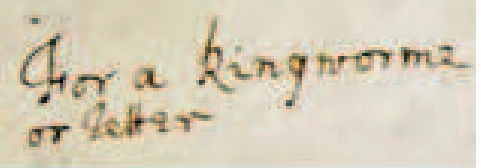

Fig. 22. Hand C (f. 45v)

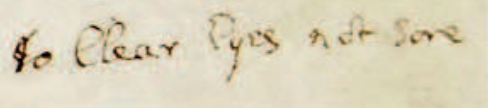

Fig. 23. Hand C (f. 76r)

\subsubsection{Numerals}

H135 presents Roman numerals in the body of the text, while Arabic numerals are employed in the numeration of the folios (see 3.1.5 above). According to Hector, the Roman system was employed in England "for about five centuries after the Norman Conquest [...] and they continued to be written in English archives long after Arabic numerals had become commonplace." 49

The Roman numerals in H135 are used to indicate the specific quantities of herbs or substances in the preparation of ointments and salves (in the surgical treatise) together with the preparation of drinks and medicines (in the remedies).

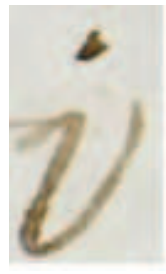

Fig. 24. One (f. 40r)

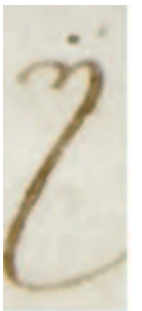

Fig. 25. Two (f. 46v)

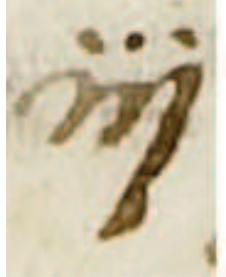

Fig. 26. Three (f. 106v)

Figures 24, 25 and 26 are the representation of numbers 1, 2 and 3, respectively. As shown, these numbers are composed of $i$ 's where, when alone or in final position, the $i$-longa is preferred ${ }^{50}$. Thus, ' $\mathrm{j}$ ', 'ij' and 'iij' stand stand for 1,2 and 3 , respectively.

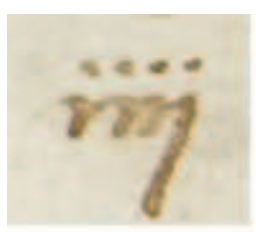

Fig. 27. Four (f. 34r)

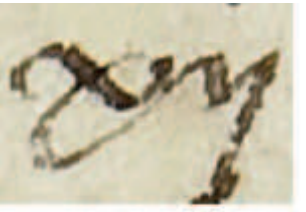

Fig. 28. Fourteen (f. 27r)

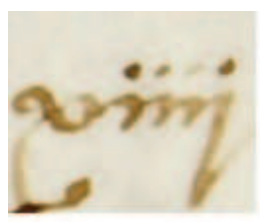

Fig. 29. Fourteen (f. 57r)

\footnotetext{
${ }^{49}$ L. C. Hector, op. cit., pp. 41-42.

${ }^{50}$ S. A. Tannenbaum, op. cit., p. 153; N. Denholm-Young, op. cit., p. 79.
} 
Number 4 can be witnessed in two different forms in H135. On the one hand, it can follow the sequence that has been explained above, by adding one more $i$ to number 3 (Figures 27 and 29), or a single $i$ accompanied by the Roman numeral $v$ (Figure 28). While the form in Figure 27 is always witnessed when number 4 stands alone, some variation is found when it is part of a higher number.

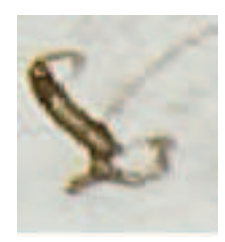

Fig. 30. Five (f. 60v)

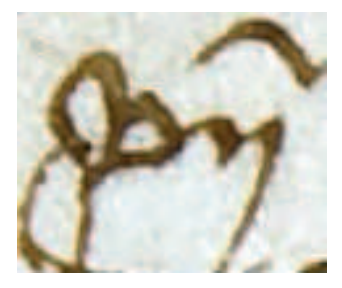

Fig. 31. Seven (f. 118v)

Number five is rendered with the Roman numeral $v$, as in Figure 30 above. In addition, the sequences in Figures 24, 25 and 26 are added to create higher numerals (Figure 31). In this same vein, number ten is represented with the Roman numeral $x$ (Figure 32), where the same sequences are added to form the other numerals (Figures 28, and 33, 34, 35, 36 and 37).

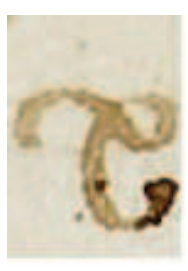

Fig. 32. Ten (f. 76r)

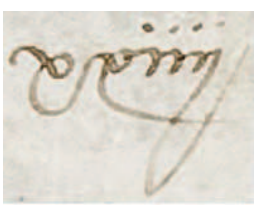

Fig. 35. Twenty-four (f. 82v) Fig. 36. Thirty (f. 107r)

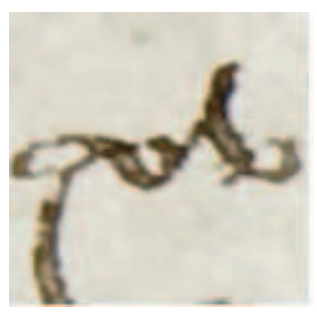

Fig. 34. Fifteen (51v)

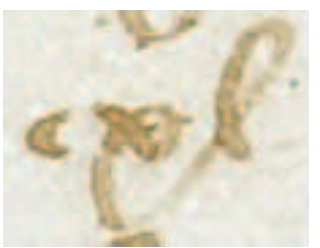

Fig. 37. Sixty (f.76r)

Apart from Roman numerals, Arabic numerals are also found, albeit to a much lesser extent. These Arabic numerals serve not only for foliation purposes, but also for the same usages as Roman numerals. 


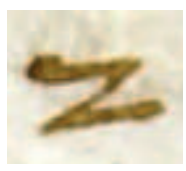

Fig. 38. Two (f. 116r)

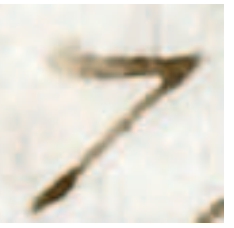

Fig. 41. Seven (f. 120v)

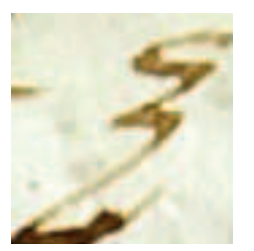

Fig. 39. Three (f. 116r)

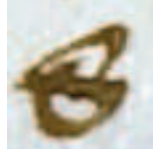

Fig. 42. Eight (f. 118v)

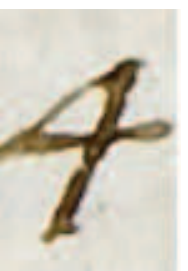

Fig. 40. Four (f. 100v)

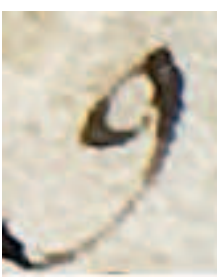

Fig. 43. Nine (f. 120v)

\subsubsection{Marginalia}

The marginalia could be used for different purposes in handwritten documents. In H135, it is used for reference purposes. Thus, there are numerous annotations indicating the topic under discussion, explanations of the particular indications, and references to other manuscripts. These inscriptions are made by the three different hands that have been identified in section 3.2.1.

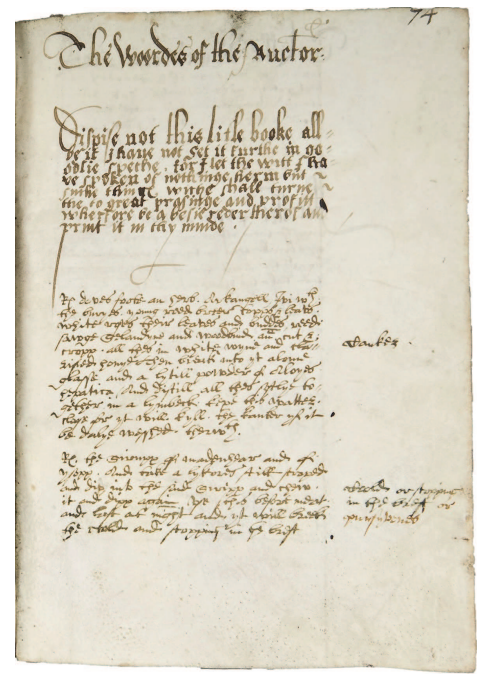

Fig. 44. Marginalia in f. 74

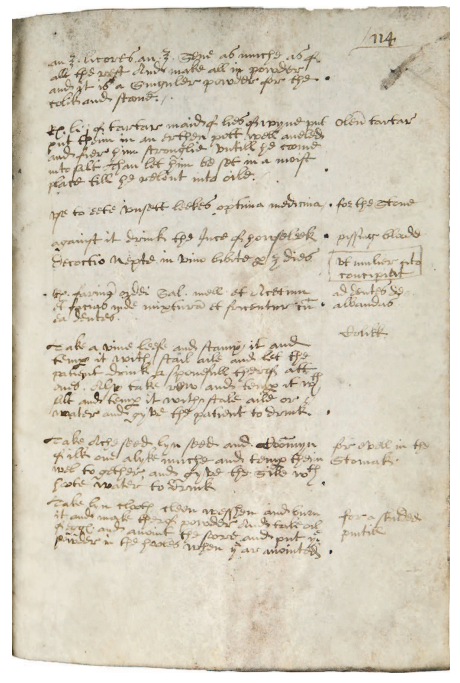

Fig. 45. Marginalia in f. 114r 


\subsubsection{Abbreviations}

In the mediaeval period, it was commonplace among scribes to abbreviate words, a practice imported from Latin and eventually transferred to the vernacular. ${ }^{51}$ From a chronological point of view, English documents of the twelfth century display the abbreviation system in the most elaborate form, while in the latter Middle Ages some of them were gradually discarded. ${ }^{52}$ Derolez notes that genre is found to play an important role in the use of abbreviations,

\section{[...] as scholastic manuscripts and those of the thirteenth and fourteenth centuries in general contain without doubt the largest number of abbre- viations (mostly specific to the subject concerned: theology, philoso- phy, law, natural science, medicine...), but the degree of abbreviation is far less in liturgical and literary manuscripts. ${ }^{53}$}

The use of abbreviations in the sixteenth century follows the mediaeval tradition, as "the need for them had become less acute as paper became more available." ${ }_{54}$ As a piece of sixteenth-century English Fachprosa, H135 contains a great deal of abbreviations, allowing the scribe to save both time and labour. The methods of abbreviation during the English Renaissance were the following: contraction, elision, absorption, curtailment, brevigraphs, superior letters and a combination of these. ${ }^{55} \mathrm{H} 135$, however, only features contractions, curtailment, brevigraphs and superior letters.

\subsubsection{Contraction}

Contraction is one of the commonest methods of abbreviation, consisting in the omission of one or more letters within a word, where the number of omitted letters could vary greatly from one scribe to another. ${ }^{56}$ These contractions were rendered by means of the tilde, the most frequent symbol in this kind of abbreviations. ${ }^{57}$ In $\mathrm{H} 135$, this method was employed to omit one single letter in the middle of a word, as in Figures 46, 47 and 48.

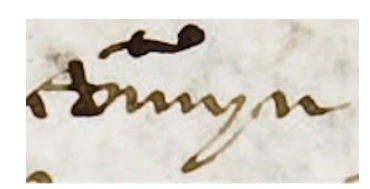

Fig. 46. 'commyn' (f. 118r)

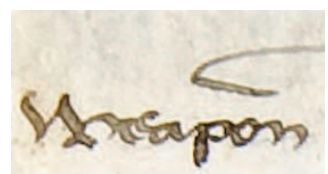

Fig. 47. 'weapone' (f. 34v)

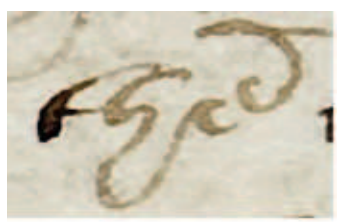

Fig. 48. 'then' (f. 36r)

\footnotetext{
${ }^{51}$ S. A. Tannenbaum, op. cit., p. 119.

${ }^{52}$ L. C. Hector, op. cit., p. 29.

${ }^{53}$ A. Derolez, op. cit., p. 187.

${ }^{54}$ G. E. Dawson and L. Kennedy-Skipton, op. cit., p. 19; J. I. Whalley, English Handwriting 1540-1853, Her Majesty's Stationery Office, London, 1969, p. ix.

${ }^{55}$ S. A. Tannenbaum, op. cit., p. 119.

${ }^{56}$ Loc. cit., p. 119.

${ }^{57}$ A. G. Petti, op. cit., p. 22.
} 


\subsubsection{Curtailment}

Curtailment, also termed suspension, was the shortening of the end of the word. ${ }^{58}$ This method of abbreviation was occasionally marked with a horizontal bar above the terminal part of the word (Figures 49, 50 and 51).

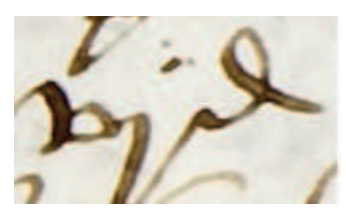

Fig. 49. '6 days' (f. 99r)

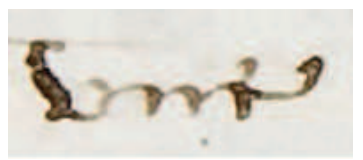

Fig. 50. 'vnce' (f. 42v)

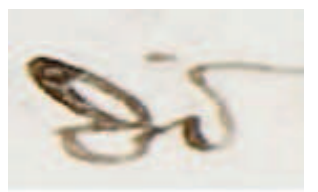

Fig. 51. 'half' (f. 42v)

\subsubsection{Brevigraphs}

Brevigraphs are regular letters that have been slightly modified for a particular purpose, either a single letter or an entire syllable. Brevigraphs, taken from Latinate texts, were frequently used for words or syllables so that time and material could be saved. ${ }^{59}$. When it comes to brevigraphs in $\mathrm{H} 135$, letter $\langle\mathrm{p}>$ is the brevigraph par excellence, as it is the source letter for four different syllables: 'pro' (Figure 52), 'per' (Figure 54), 'pre' (Figure 53) and 'pri' (Figure 55). In addition, a symbol resembling a 9 (Figure 56) is used to abbreviate the group $<$ us $>.60$

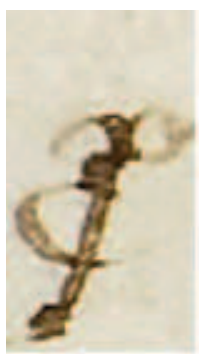

Fig. 52. 'pro'

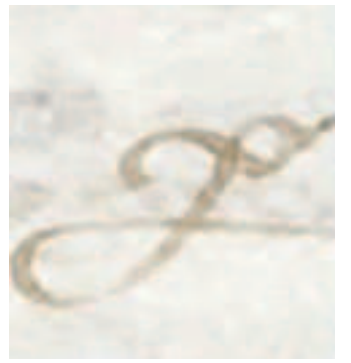

Fig. 53. 'pre'

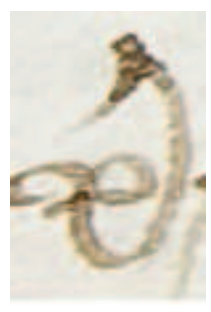

Fig. 54. 'per'

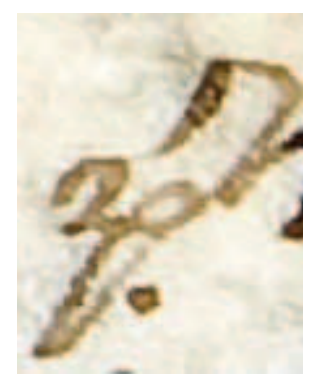

Fig. 55. 'pri'

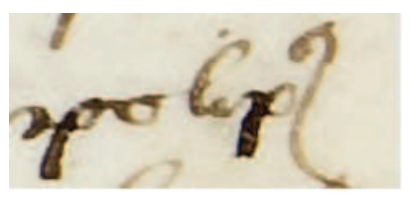

Fig. 56. 'polipus'

${ }_{58}^{5}$ S. A. Tannenbaum, op. cit., p. 124.

${ }^{59}$ Loc. cit., p. 124.

${ }^{60}$ Loc. cit., p. 127. 


\subsubsection{Superior letters}

Superior letters were used to omit one or more letters, and they were placed above the line to indicate the omission. This abbreviation technique could be applied to all words and the number of omitted letters could vary depending on the scribal habit. The following superior letters can be highlighted in H135.

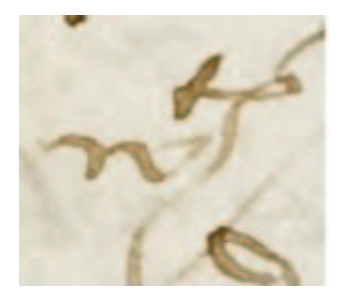

Fig. 57. 'with'

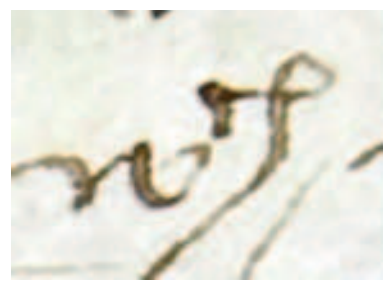

Fig. 58. 'which'

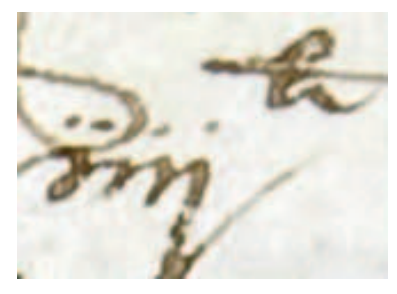

Fig. 59. 'Four pounds'

Apart from the use of superior letters for abbreviation, there are common words in the text in which the final letter(s) are above the line as a custom of the scribe, not strictly standing for an abbreviation in itself.

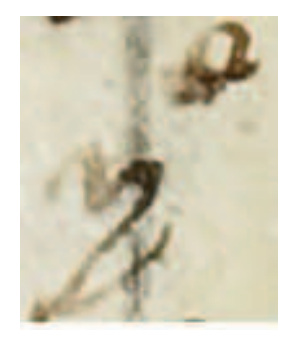

Fig. 60. 'pe'

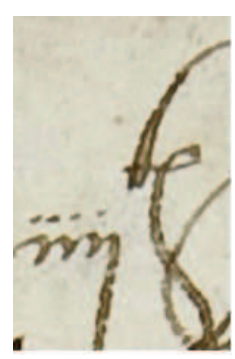

Fig. 61. 'fourth'

\subsubsection{Manuscript corrections and scribal errors}

Scribes had the common practice of revising their work when they had finished copying a text in order to detect any likely error they could have committed. In this line, Hector distinguishes two different kinds of scribal errors: those that scribes have noticed and properly corrected and those that they have left for us to detect and analyse ${ }^{61}$. Among those scribal errors that remained unnoticed during the stages of revision, H135 displays the following:

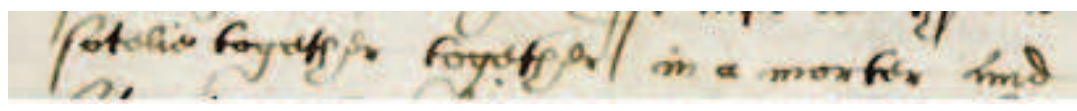

Fig. 62. Addition (f. 47v)'sotelie together together in a morter and'

\footnotetext{
${ }^{61}$ L. C. Hector, op. cit., p. 49.
} 


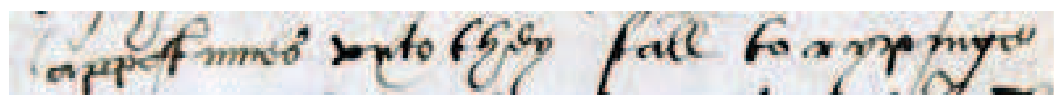

Fig. 63. Syllable addition within a word (f. 49v)'apopostumes vnto they fall to rypinge'

Besides these unnoticed errors, the scribe of $\mathrm{H} 135$ carried out manuscript corrections by deletion, alteration and insertion. ${ }^{62}$ These are explained below with the corresponding fragment in which they appear.

\subsubsection{Deletions}

H135 presents three deletion techniques: cancellation, expunction and erasure. Cancellation is the most frequent type of correction in the witness and consists in striking through the passage with ink with one or more straight lines (Figures 64 and 65). Figures 66 and 67, in turn, are instances in which the scribe uses cancellation in order to amend another scribal error consisting in the "mechanical repetition of a syllable, word or phrase through a lapse of memory or a trick of sight, an error of dittography." 63

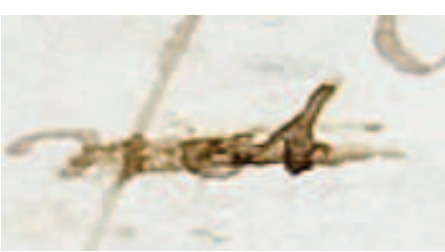

Fig. 64. Cancellation (f. 80r) 'not'

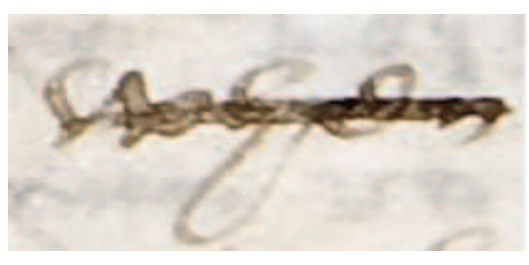

Fig. 65. Cancellation (f. 37r)'when’

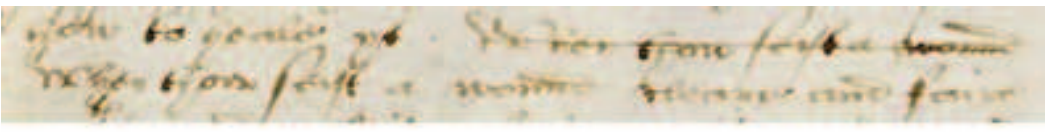

Fig. 66. Cancellation (f. 58r) 'how to heale yt.

When thow seist a wound when thow seist a wound cleare and faire'

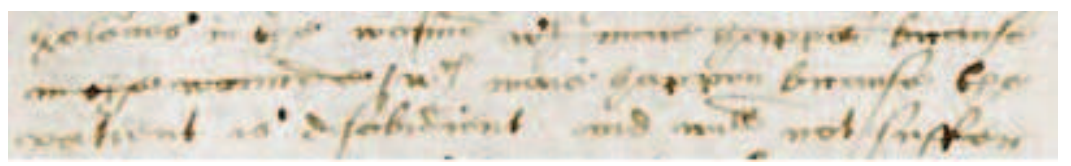

Fig. 67. Cancellation (f. 58v)

'holones in the wound which maie happen beeause in the wounde /

which maie happen because the patient is disobidient and will not suffer'

Expunction only appears once in the manuscript and is rendered by placing a dot under each letter to be left out ${ }^{64}$, as in Figure 68.

\footnotetext{
${ }^{62}$ A. G. Petti, op. cit., p. 29.

${ }^{63}$ A. G. Petti, op. cit., p. 30.

${ }^{64}$ Loc. cit., p. 29; R. Clemens and T. Graham, op. cit., p. 35.
} 


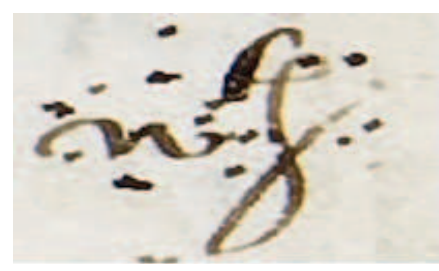

Fig. 68. Expunction (f. 45r) 'with'

Erasure consists in the removal, with a sharp knife, of the surface to be deleted and the posterior inclusion of the correct letter in the erased place. ${ }^{65}$ Figures 69 and 70 are an example of erasure, in which the erased surface can be detected in view of the darkness left by the scraped ink.

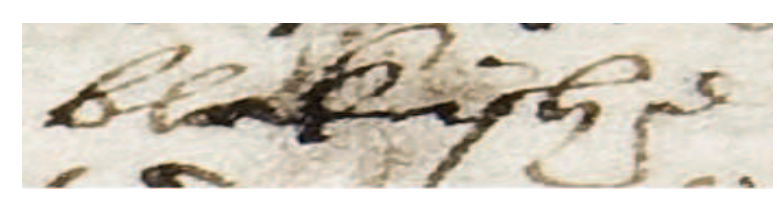

Fig. 69. Erasure (f. 43r)'blakishe’

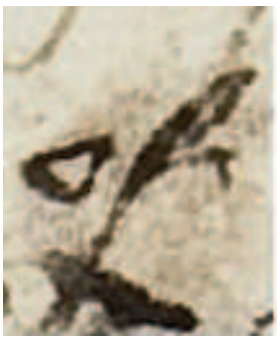

Fig. 70. Erasure (f. 43r)'of'

\subsubsection{Alterations}

Alterations are "modification of letters or words by superimposing or superscribing the correct letter on the deleted one." 66 In Figure 71, the scribe had formerly written $\mathrm{a}<\mathrm{g}>$ instead of $\mathrm{a}<\mathrm{c}>$.

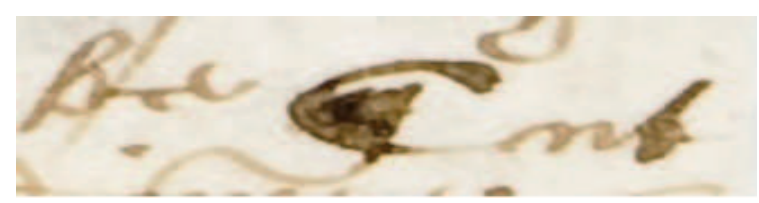

Fig 71. Alteration (f. 59r)'Be Cut'

\subsubsection{Insertions}

Insertions could be performed directly on the line or above it (interlineation), depending on the length of the insertion, as they could be words, phrases and clauses. The caret $\left(^{\wedge}\right)$ was used to mark the point in which the fragment was to be inserted. ${ }^{67}$ Insertions are made by the same scribe who copied the text (Figures 72, 73, 74 and 75) or by a later hand (Figure 76 and 77).

${ }^{65}$ L. C. Hector, op. cit., p. 49; R. Clemens and T. Graham, op. cit., p. 35.

${ }^{66}$ A. G. Petti, op. cit., p. 29.

${ }^{67}$ Loc. cit., p. 29. 


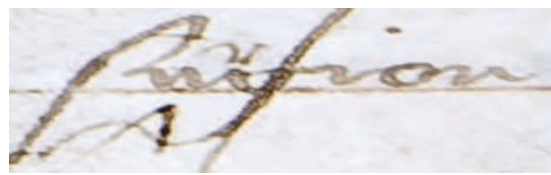

Fig. 72. Insertion (f. 38r)'sur/r/gion’

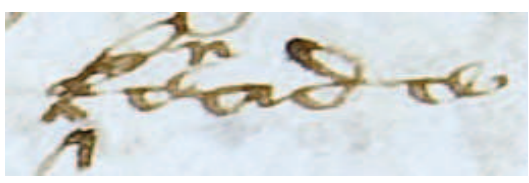

Fig. 73. Insertion (f. 62r)' $\mathrm{k} / \mathrm{n}$ leade'

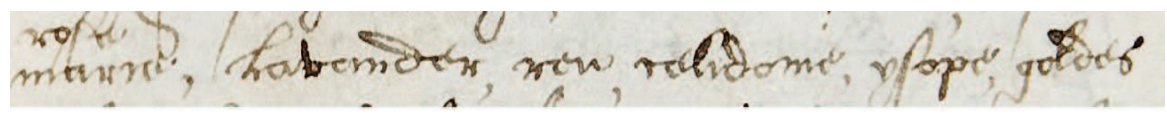

Fig. 74. Insertion (f. 72r) /rose $\backslash$ marie, lavender, rew, celidonie, ysope, goldes

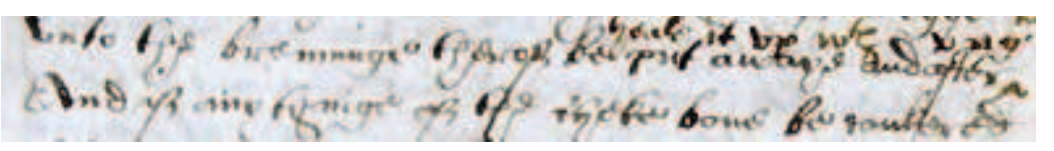

Fig. 75. Insertion (f. 44v)

'vnto the brenninge therof be put awaye and after/

heale it vp with vnguentum viride $\backslash$ And if any thinge of the cheke bone be cankered'

Figures 72 and 73 show the insertion of one missing letter in a word, where the scribe inserts it above the line, the caret marking its appropriate place. Figure 74 presents the insertion of a whole word above the line without the caret (most likely due to the obvious pairing of the words 'rose' and 'marie'). Finally, figure 75 accounts for the insertion of a whole clause above the line, the caret marking the exact point of the insertion.

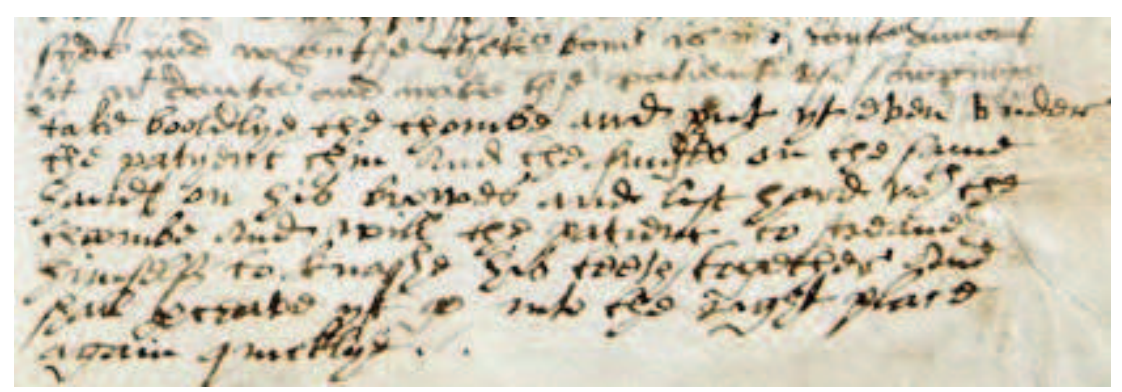

Fig. 76. Insertion (f. 44r)

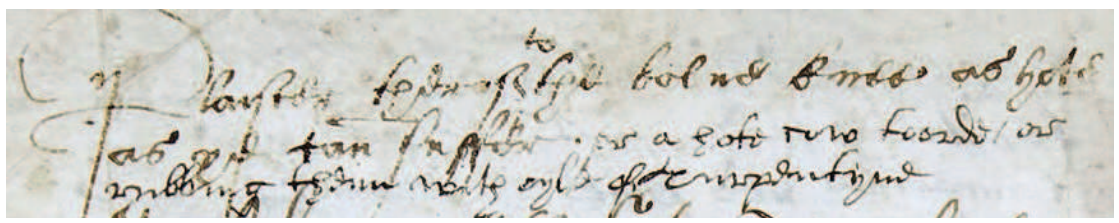

Fig. 77. Insertion (f. 93v) 
Figures 76 and 77 are instances of insertions by a later hand, as a change in the handwriting is easily noticed. Figure 76 shows a whole paragraph inserted at the bottom margin of $\mathrm{f}$. 44r, incorporating extra information to the topic under discussion. The source of the added information is unknown. Figure 28, in turn, shows a smaller insertion, barely a clause, which is providing two alternative remedies to the one that has been proposed. The source of this insertion is MS Hunter 251 (U.4.9), which appears referred as 'Dr. Mead's MS' in later insertions in the volume. ${ }^{68}$ These two hands carry out a great number of insertions and corrections throughout the text, the marginalia and the indexes.

\section{Conclusions}

The present paper discussed the contents, ownership and physical description of H135, an early Modern English Scientific volume containing a surgical treatise and a collection of medical recipes. The following conclusions have been obtained.

The existence of three different tables of contents demonstrates that the volume was used for different purposes, as the different sections are given more or less importance depending on the table of contents. Moreover, this also indicates that the volume was owned by different people, who would ultimately create their tailored tables of contents. These people have been identified by way of three inscriptions, i.e. Henry Swinburne, Leonardus Cooke and, finally, William Hunter owned the volume.

The physical description has also shed light on the likely date of composition of H135 as well as some of the practices in early Modern English manuscript production. On the one hand, the codicological analysis shows that the volume complies with the typical characteristics of sixteenth-century scientific manuscripts due to features such as binding or foliation, to name but two. On the other, the palaeographic analysis of the three different hands in the witness concludes that the manuscript was likely composed towards the middle of the sixteenth century, as the main hands are in fact hybrid scripts composed of an early Tudor Secretary hand together with some characteristic features of the mid-Tudor Secretary and the Italic.

${ }^{68}$ J. Young y P. Henderson-Aitken, op. cit., pp. 201-202. 